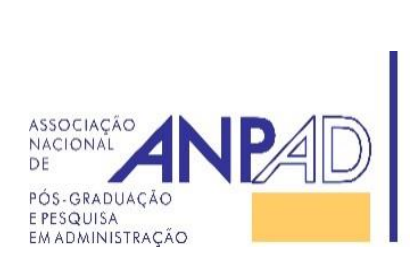

Available online at http://www.anpad.org.br/bar

BAR, Rio de Janeiro, v. 14, n. 2, art. 5, e160100, 2017

\title{
Co-evolution of Industry Strategies and Government Policies: The Case of the Brazilian Automotive Industry
}

Roberto Gonzalez Duarte ${ }^{1}$ Suzana Braga Rodrigues ${ }^{2,3}$

Universidade Federal de Minas Gerais ${ }^{1}$ Erasmus University Rotterdam, Rotterdam School of Management ${ }^{2}$ Universidade FUMEC ${ }^{3}$

Received 15 October 2016; received in revised form in 4 July 2017 (this paper has been with the authors for two revisions); accepted in 5 July 2017; first published online 28 July 2017. Editor's note. Jorge Carneiro served as Associate Editor for this article. 


\begin{abstract}
This study examines the evolution of the automotive industry in Brazil and its key drivers. We argue that the rules of the game - industry policies - are an outcome of exchanges between the host government and industry. These arise from changes in economic and political environments and interdependence between industry and the country's economy. To this end, we draw upon literature on institutions and co-evolution to understand the industry footprint over a 50-year period, as well as its relationship with changes in government policies. This study generates new insights on institutional and co-evolution political perspectives by showing that the rules of the game are not only the making of the government, but are also the result of interdependencies between industry and government.
\end{abstract}

Key words: co-evolution; government-industry interaction; emerging markets; automotive industry; rules of the game. 


\section{Introduction}

The literature on international business has largely demonstrated how host country institutions, through the actions of their governments, can influence multinational enterprises' (MNEs) choice of location (Lu, Liu, Wright, \& Filatochev, 2014), mode of entry (Henisz \& Zelner, 2005), and performance (Cuervo-Cazurra \& Dau, 2009). In turn, home country government institutions, through formal and informal mechanisms, can foster the internationalization process of national MNEs (Bazuchi, Zacharias, Broering, Arreola, \& Bandeira-de-Mello, 2013; Dunning \& Lundan, 2008).

The political intricacies in relationships between MNEs and (host and home) governments (or the influence one side exerts over another) have chiefly been examined in by corporate political activity (CPA) literature (Bazuchi et al., 2013; Fernandes, Bandeira-de-Mello, \& Zanni, 2012). Rajwani and Liedong (2015), showing that CPA adds value to the firm. Nevertheless, firm choices and political strategies are conditioned by the institutional environment. For instance, in contexts of institutional weakness, which are typical in emerging economies, these political strategies may be better understood through the concepts of social capital and political connections. From a broader theoretical viewpoint, Lawton, McGuire, and Rajwani (2013) argue that institutional theory can contribute in two ways to our understanding of CPA: firstly, "it can give an account of how different political, social and economic arrangements affect firm-government relations"; secondly, at the firm level, institutional theory can help us "to understand how firms adapt (or not) to alterations and evolution in the non-market environment" (p. 92). The latter issue, as the authors argue, is particularly important in emerging markets, "where economic development can place traditional institutional arrangements under strain" because "the evolution of a political system can present incumbent firms with difficulties, as their previous CPA is rendered less effective in the new context" (Lawton, McGuire, \& Rajwani, p. 96). For these authors, a question that remains and must be further explored relates to understanding non-market activity in emerging economies. These prior studies on the relationships between institutions and firms, including MNEs, have empirically and theoretically illuminated how CPA can affect firm outcomes due to government regulations. In spite of the relevance of this literature in clarifying the political arena in which business and government interact, and how this interaction affects firm performance, they do not focus on the process of institution-building over long periods of time.

These studies have also looked more closely at the firm level than others, such as industry. In our study, we analyze how governments in emerging economies interact with local industries. The choice of industry as a unit of analysis is due to a number of reasons. First, government regulation does not address individual firms, but a collection of firms that are similar in the type of business or segment in which they operate. Second, firms in the same sector tend to respond isomorphically by imitating the practices and strategies of peers (DiMaggio \& Powell, 1983; Kostova \& Roth, 2002). Third, in some emerging economies such as Brazil, the state played a critical role in fostering the development of several industrial sectors, with business and governments maintaining close relationships. This closeness translates into large government subsidies and protection (Schneider, 2015). Fourth, the interaction between industry and successive governments of developmental states over time brings to the fore an issue that contributes to our understanding of the process of institution-building - that is, the interdependence between industry and a country's economy - and, more precisely, between industry outcomes and a country's economic performance. We argue that interdependence is a key driver of the co-evolutionary process, particularly regarding the definition of the rules of the game.

Drawing on institution and industrial policy literature, our research investigates how institutions, which are "the humanly devised constraints that structure human interaction" (North, 2001, p. 248), come into being and influence the strategic choices and performance of the Brazilian automotive industry. More specifically, we look at formal industry constraints, such as the rules of the game (e.g., government regulations and policies). We understand rules of the game to mean actions and policies by governments that attract and regulate the development of an industry. We also analyze how these formal institutions change over time because, as North (1990) argues, "institutional change is shaped by 
(i) the lock-in that comes from the symbiotic relationship between institutions and the organizations that have evolved as a consequence of the incentive structure provided by those institutions" (p. 7).

Our purpose is to analyze institution-building within the context of a developmental state. As Scott (2008) states,

attention has been devoted to how institutions affect the structure and functioning of organizations, organizational populations, or organizational fields, but much less to understand how institutions are constructed, the actors implicated in this process, forces by which new types of institutions emerge and the mechanisms by which they are crafted (p. 93).

Our purpose is to analyze institution-building within the context of an emerging economy where the state was a critical force for industrial development, and where interdependence can be seen as a mechanism that drove the rules of the game defined by the state.

Given that industrial policies vary within and across political mandates and economic circumstances in host countries, we used a co-evolutionary perspective to construct a framework that explains the context and mechanisms by which the rules of the game emerge and change. Even though most co-evolutionary studies have focused on individual firms and how they relate to their meso (industry) and macro (institutional) environments, some recent co-evolution studies have focused on the industry level (Breznitz, 2007; Funk, 2009; Murmann, 2013). These studies have sought to clarify how the interaction between government and industry over time can affect industry outcomes and explain government policy effectiveness - or, in the case of Murmann's study (2013), causal mechanisms that drive co-evolution.

Moreover, by examining the dynamics driving and shaping the interaction between government policies and industry strategies, our main aim is to advance a political perspective of co-evolution (Child, Tse, \& Rodrigues, 2013; Dieleman \& Sachs, 2008; Rodrigues \& Child, 2003). The economic and political volatility exhibited in the history of emerging markets renders industry-institution coevolutions an important and attractive subject for research. Yet, with a few exceptions (Child et al., 2013; Dieleman \& Sachs, 2008; Rodrigues \& Child, 2003), this has been somewhat overlooked in the co-evolution literature up to now. Such a perspective draws attention to the intentionality and importance of power of relevant actors. Since firms and other actors have their own interests, they consciously drive co-evolutionary processes through certain initiatives (Child et al., 2013). Our intent is to expand a political approach by looking at another aspect: how high or low interdependence affects the interaction between industry and government and, thus, the rules of the game defined by the latter for the former.

This study examines the Brazilian automotive industry and addresses the role of interdependence in the co-evolution of government and industry strategies. We selected the automotive industry for analysis due to four reasons: (a) usually this industry engages in CPA (Eden \& Molot, 2002; Sun, Mellahi, \& Wright, 2012; Zhao, Anand, \& Mitchell, 2005); (b) the Brazilian automotive industry is entirely foreign owned (Shapiro, 1994); (c) the automotive industry is perceived as having a high degree of legitimacy due to its historical role in the country's industrialization process - automobiles have been at the center of Brazilian industrial policy for more than 50 years (Financial Times, 2013); and (d) the importance that the automotive segment has for the Brazilian economy as a whole - the sector, on average, has accounted for 15\% of Brazilian industrial GDP over the last two decades. This importance has led, as Schapiro (2017) contends, to the automotive industry being a permanent client of different government incentive schemes, regardless of their ideological orientation.

We examine the industry's footprint and changes in industrial policies over a 50-year period. In this longitudinal case study on the Brazilian automotive industry, we develop a conceptual framework that recognizes interdependencies and interest-based exchanges; the nature of outcomes - the rules of the game; and industry choices regarding production, technology, and trade. In particular, this study examines how these rules emerged and changed over time as well as their effect on the performance of the automotive industry. Through a co-evolutionary perspective, we unveil how the evolution of political and economic contexts over five decades has led to more or less interdependence between the 
automotive industry and Brazilian economy, thus affecting reciprocal adjustments and the definition and change of rules. By doing so, we advance a political co-evolution perspective by drawing attention to the role of interdependence as a driver of the process.

The rest of this paper is structured as follows. First, we introduce a co-evolution perspective and how it throws light on the abovementioned issues. Second, we discuss how the rules of the game and politics are interrelated in emerging economies. We then explain the methods used. A section on findings explores the mutual effects of government and industry strategies and the outcomes of this process in different economic and political challenges. The final section integrates our findings on four periods of industry co-evolution and provides research conclusions.

\section{A Political View of Industry Co-evolution}

Co-evolution has opened avenues to explore how interdependent actors - organizations, industries, and institutions - mutually influence each other and to understand how these economic entities develop interactively over time (Child, Rodrigues, \& Tse, 2012; Rodrigues \& Child, 2008). Coevolutionary analysis requires an examination of the interaction between organizations (micro level) and their immediate (meso level) or broader (macro level) environments.

Research on different industries - such as synthetic dye (Murmann, 2013), oil (Dantas \& Bell, 2011), film (Lampel \& Shamsie, 2003), financial services (Flier, Van den Bosch, \& Volberda, 2003), music (Huygens, Van den Bosch, Volberda, \& Baden-Fuller, 2001), and fashion (Djelic \& Ainamo, 1999) - has helped to explain how "environmental transformation and organizational change interact over time and feed on each other" (Djelic \& Ainamo, 1999, p. 622). More precisely, research has explained the interaction between, on the one hand, "internal processes such as the variation and replication of routines, capabilities, competencies and, on the other, industry-level competitive dynamics and selection" (Lewin \& Koza, 2001, p. vi). Thus, industry capabilities may be understood as "systemic properties that result from the behavior of firms acting to improve their position within this ecology by searching for new practices and routines" (Lampel \& Shamsie, 2003, p. 2206). These studies have provided information on the role of managerial intentionality within firm adaption processes (Lewin \& Volberda, 1999) and, specifically, the evolution process: firms' adaptation to their environments through learning (Child et al., 2013).

Other studies have sought to extend our understanding of the dynamics of co-evolution between organizations (micro) and institutions (macro) (Child et al., 2012, 2013; Dieleman \& Sachs, 2008; Rodrigues \& Child, 2003) and between industries (meso) and institutions (Ahlstrom \& Bruton, 2010; Breznitz, 2007; Flier et al., 2003; Funk, 2009; Hoffman, 1999; Jain \& Sharma, 2013; Murmann, 2013). Both approaches appreciate the value of environments, historical legacies, institutional contexts of countries in shaping organizations' trajectories, and their structural evolution over time (Djelic \& Ainamo, 1999). Nevertheless, organizations may perform the role of institutional entrepreneurs and proactively change their environments (Child, Lu, \& Tsai, 2007; Dieleman \& Sachs, 2008). A similar point in these studies is the assumption that while firms respond to institutional environments, they also change these environments. Some examples include entrepreneurial firms in Russia (Ahlstrom \& Bruton, 2010), a container terminal in China (Child et al., 2013), and the mobile industry in India (Jain \& Sharma, 2013).

In addition, these Russian, Chinese, and Indian cases have shown that the co-evolutionary dynamics of influence in emerging economies may not have the same pattern as in developed economies, which typically have freer markets (Ahlstrom \& Bruton, 2010; Child et al., 2012; Dieleman \& Sachs, 2008; Jain \& Sharma, 2013; Rodrigues \& Child, 2003). Emerging economies are characterized by rapid shifts in institutional environments (Ahlstrom \& Bruton, 2010), a lack of institutional stability, and institutional weakness (Rodrigues \& Child, 2008). They are also characterized by deep political ties between corporations and institutions (Dieleman \& Sachs, 2008; Fernandes et al., 2012; Sun et al., 
2012), hierarchical structures (Schneider, 2009), and network capitalism (Musacchio \& Lazzarini, 2014), in which firm strategies are defined by cozy relationships with the state rather than by market relationships.

The roles of politics and power within co-evolutionary processes have been empirically analyzed, establishing the foundations for building a political view of co-evolution. Rodrigues and Child (2003), who examine the case of a state-owned Brazilian telecommunications firm (Telemig) within a highly institutionalized environment, argue that "senior managers are able to influence the institutional environment - and therefore the competitive regime - by holding positions that allow them to engage in political actions that redefine regulatory boundaries [among others]" (p. 2160). Later, Dieleman and Sachs (2008) examine the case of Indonesia's Salim Group. The influence of this family-owned business over local institutions was possible because it "was embedded in the Suharto regime, and through its connections was able to modify its external environment to fit its own needs" (Dieleman \& Sachs, 2008, p. 1297). Finally, more recently, by analyzing the case of China's Yantian International Container Terminals (YICT), which, like Telemig, operates within a context characterized by a high level of government intervention, Child, Rodrigues and Tse (2012) advanced a co-evolution political perspective by discussing how intentionality and power resources of relevant actors create possibilities for them to influence co-evolution. Their argument is that "co-evolution takes place not only through learning, but significantly through the use of power and influence" (Child et al., 2012, p. 1247).

These studies shed light on issues such as the dynamics of co-evolution and, in particular, the construction of institutions. One issue is institutional endogeneity - the possibility that institutions can be influenced by organizations (Dieleman \& Sachs, 2008). This is particularly important in emerging economies, in which leading firms are often in a position to advance governments' interests (such as support for education and other social programs) in return for flexibility in how regulations apply to them (Child et al., 2013). Another issue is the political nature of the interaction of firms, the government, and institutions (Rodrigues \& Child, 2008), which is an important aspect to examine in co-evolutionary dynamics.

Two aspects have been disregarded in this political view of co-evolution. First, focus has been on corporate co-evolution, so the unit of analysis is the firm. Previous studies have analyzed micro (organization) and macro (institutional) interactions by examining the cases of three single firms (Telemig in Brazil, the Salim Group in Indonesia, and YICT in China). In the present study, we focus on the interaction between meso (industry) and macro (institutional) levels, examining how the result of their interaction - the rules of the game - is influenced by their interdependencies. In some developmental states in East Asia and Latin America, the state played an active role in fostering the development of chosen industries. The development of these industries, such as the automotive in Brazil, was marked by certain features: reciprocity (subsidies in exchange for improved performance) and collaborative relations between government and business (Schneider, 2015). As co-evolution theory suggest, these relationships create path dependence, setting the basis for the type of interdependence governments and industry develop.

Second, a political perspective draws attention to intentionality and power resources of relevant actors as drivers of the co-evolutionary process (Child et al., 2013); however, it has overlooked the role of interdependence in co-evolution dynamics. As industries evolve and become more important within a country's economy, their interests can become closely linked to those of governments. This interdependence, which is well illustrated by the Brazilian automotive industry (Schapiro, 2017), may have effects on how the rules of the game are defined and change over time. Institution-building is thus path dependent, reflecting reciprocity and collaborative relations between business and government (Schneider, 2015) or the lock-in suggested by North (1990). It also reflects more circumstantial interdependences, which vary according to economic and political contexts. We therefore argue that in addition to intentionality and power resources of relevant actors, a political perspective should draw attention to interdependence as a driver of co-evolution between industry and institutions in developmental states. 


\section{Defining the Rules of the Game in Emerging Economies}

Institutions are defined as formal and informal rules of the game (North, 1990). Rules govern the interactions of actors - MNEs, domestic firms, civil society groups, and government bodies - and determine the organization of economic activities (Fligstein, 2001). Although the effects of institutions on organizations have been widely analyzed from different theoretical perspectives, less attention

has been devoted to how institutions affect the structure and functioning of organizations, organizational populations, or organizational fields, but much less to understand how institutions are constructed, the actors implicated in this process, forces by which new types of institutions emerge and the mechanisms by which they are crafted (Scott, 2008, p. 93).

Understanding how actors play the game of defining rules is, however, not so simple given the different forces at play (Biggart \& Guillén, 1999; Nelson, 1995; Rodrigues \& Child, 2008). Stopford (1994) asserts that,

the rules of the game are determined by the outcomes of a three-way tug of war: domestic political imperatives pull one way; international economic imperatives can pull in another; and the firms' global competitive imperatives can add a third dimension (p. 54).

As North (1990) states, "institutions are not necessarily or even usually created to be socially efficient; rather they, or at least the formal rules, are created to serve the interests of those with the bargaining power to devise new rules" (p. 16). The strength (or power) of each way pulling against the others is highly contextual, so there tends to be a difference between developed markets and emerging economies. In the latter context, characterized by the absence of strong institutions (Lawton et al., 2013), powerful actors are more likely to engage in political behavior to protect their interests. In reality, the institutional context "influences the political strategies used by firms, the performance outcomes of those strategies, and the mechanisms through which those strategies affect performance outcomes" (Rajwani \& Liedong, 2015, p. 274).

Government-firm relationships are embedded in historical and structural conditions that prevailed at the time of an industry's inception (Schneider, 2009). An example is the way in which countries developed their political and economic regimes. Industrialization in emerging markets in Asia and Latin America followed a model of development in which relationships between the state and private firms were central. Local governments defined policies that shaped their countries' relationships to the global economy and affected the domestic allocation of resources in industries and major social groups (Gereffi, 1990; Schneider, 2015). In order to leverage industrialization, emerging economy governments used several strategies to attract foreign capital in order to subsidize the development of more technologically sophisticated industries. These strategies gave rise to a debate about the "relative power of foreign actors and Third World governments in determining rules for investment and the distribution of benefits" (Stallings, 1990, p. 55).

In the particular case of Brazil, industrialization was leveraged by the state, MNEs, and local capital (Evans, 1979). The role played by economic agents during certain phases varied. When there was an attempt between the mid-1950s and mid-1960s to substitute capital - and technology-intensive products, such as automobiles, electrical and non-electrical machinery, petrochemicals, and pharmaceuticals - MNEs played a major role in the process. As industrialization proceeded, a new structure of power was established. State-owned firms, along with MNEs and large-scale private firms, dominated the Brazilian industrial regime in this period (Kaufman, 1990). Assessments of the development of MNEs in Brazil (Grosse, 2013; Lazzarini, Musacchio, Bandeira-de-Mello, \& Marcon, 2015; Schneider, 2009; Stallings, 1990) have suggested that government-business relationships played a central role given the state's multiple roles as a competitor, supplier, and regulator (Grosse, 2013). Schneider (2009) argues that in Latin America, relationships between the state and firms were shaped by hierarchical capitalism, in which the value of market rules varied with the political preferences of those in power. Even in regimes in which market relationships were of some value, such relationships 
predominated until the state decided to interfere in a way that was beneficial to its political interests. Although the role of the state can diminish in pro-market governments, they often decide to recover their historical roles (Cuervo-Cazurra, Inkpen, Musacchio, \& Ramaswamy, 2014).

Despite acknowledging the political dimension of the relationship between MNEs and institutional environments (Boddewyn \& Brewer, 1994), this approach downplays the relationship between industry and the government. A host government certainly deals with individual organizations, but some industries are highly concentrated, with only a few relevant actors and, thus, interaction between industry and the government deserves attention. This approach also overlooks how relationships with governments and institutions evolve over time, especially regarding changes to, and the definition of, the rules of the game. Neglect of the processual characteristic of the definition of rules may overlook the "messy political facets that characterize institutional change" (Jain \& Sharma, 2013, p. 253). These facets are even more important in emerging economies, where the interplay between politics and institutions is more obvious (Meyer \& Peng, 2016; Rodrigues \& Child, 2008) but still not entirely clear (Peng, Wang, \& Jiang, 2008). Nevertheless, we can unveil how the co-evolution of macro and meso elements occurs through the use of power and influence (Child et al., 2012). Interdependencies between industry and national economies deserve further analysis, particularly how structural interdependence, which is path dependent, can be complemented by a more circumstantial interdependence that can vary with shifts in economic and political contexts.

Governments define regulations for the entire economy as well as specific industries. Industrial policies are usually associated with longer-term government plans aimed at creating and fostering the development of a particular industry. Complementarily, some rules of the game are more flexible and circumstantial as they can be granted or suspended at any time. Thus, they are more susceptible to political, economic, as well as to ideological shifts. In this study, we examine tax incentives (in different schemes) that governments may give to industries considered more important in leveraging economic development. Thus, from an institutional viewpoint, the definition of some rules may be more open to the influence of certain immediate economic and political circumstances; and such rules may also be less structural, stable, and easier to change. These circumstances are, nevertheless, moderated by lockin, which is a consequence of "the incentive structure provided by ... institutions" (North, 1990, p. 7).

\section{Methods}

To discuss the co-evolution process of industry and institutions' strategies, as well as the outcomes (the rules of the game) resulting from this interaction, we analyze the Brazilian automotive industry from a historical perspective. An essential characteristic of co-evolutionary studies is their historical and longitudinal approach (Dieleman \& Sachs, 2008; Murmann, 2013; Rodrigues \& Child, 2003). A longitudinal perspective is key in understanding how disruptive events, such as, economic downturns and new government regimes, give rise to new rules that govern industry. Although coevolution studies have typically used longitudinal studies, less attention has been paid to the role of disruptive events in the evolution of the rules of the game. One exception is the work of Hoffman (1999), who analyzes how these events lead to a reconfiguration of the institutions guiding organizations' behavior. Prior studies on co-evolution have argued that identification of macro disruptions are key to capture changes that occur at a different level of analysis (Lewin \& Volberda, 1999) - a research strategy that we used in this research that is explained below in this section.

We analyzed, over a 50-year period (1964-2014), the development of the Brazilian automotive industry in periods of high and low economic growth and under different political regimes. This division followed major national political and economic events. The first phase (1964-1974) starts with the military coup and ends around the world oil crisis. This period was characterized by rapid economic growth, which was destabilized by the oil crisis and balance of payments deficit. The second phase (1975-1989) covers a period of deep economic crisis (debt crisis, high inflation, and low economic growth) and ends with the return of democracy around 1990. The subsequent phase (1990-2002) is 
marked by economic stabilization, privatization, higher economic growth, freer trade policies, and increased exports and ends with the ascension of the Workers' Party to power in 2003. The last phase (2003-2014) is characterized by a boom in consumption and an increasingly favorable international economic environment. Table 1 presents an overview of the four phases.

Table 1

Brazil's Political and Economic Context (1964-2014)

\begin{tabular}{|c|c|c|c|c|}
\hline & $\begin{array}{c}\text { Phase I } \\
(\mathbf{1 9 6 4 - 1 9 7 4 )}\end{array}$ & $\begin{array}{c}\text { Phase II } \\
(\mathbf{1 9 7 5 - 1 9 8 9 )}\end{array}$ & $\begin{array}{c}\text { Phase III } \\
(1990-2002)\end{array}$ & $\begin{array}{c}\text { Phase IV } \\
(2003-2014)\end{array}$ \\
\hline Political Context & $\begin{array}{c}\text { - Democratic } \\
\text { regime } \\
\text { - Political } \\
\text { instability } \\
\text { - Military regime }\end{array}$ & $\begin{array}{l}\text { - End of the } \\
\text { military regime } \\
\text { - President directly } \\
\text { elected in } 1989\end{array}$ & $\begin{array}{c}\text { - Presidents } \\
\text { directly elected } \\
\text { - Impeachment of } \\
\text { President Collor } \\
\text { - Consolidation of } \\
\text { democracy }\end{array}$ & $\begin{array}{l}\text { - Political stability } \\
\text { - Ascension of the } \\
\text { Workers' Party }\end{array}$ \\
\hline $\begin{array}{c}\text { Economic } \\
\text { Context }\end{array}$ & $\begin{array}{c}\text { - Higher economic } \\
\text { growth } \\
\text { - Oil crisis } \\
\text { - Trade deficit }\end{array}$ & $\begin{array}{c}\text { - Deep economic } \\
\text { crisis } \\
\text { - high inflation and } \\
\text { recession } \\
\text { (stagflation) } \\
\text { - Debt crisis }\end{array}$ & $\begin{array}{l}\text { - Freer trade } \\
\text { policies } \\
\text { - Economic } \\
\text { stabilization } \\
\text { - Mercosur }\end{array}$ & $\begin{array}{c}\text { - Higher economic } \\
\text { growth } \\
\text { - Consumption boom } \\
\text { - Favorable } \\
\text { international conditions }\end{array}$ \\
\hline
\end{tabular}

Note. Source: Compiled by the authors.

The main data source used in our longitudinal study was the online achieve of $O$ Estado de São Paulo (ESP). We collected macroeconomic data, such as economic growth, inflation, and interest rates, from the Central Bank of Brazil (Banco Central do Brasil [BACEN]) and the Brazilian Institute of Geography and Statistics (Instituto Brasileiro de Geografia e Estatística [IBGE]). For information on the automotive industry's performance, we gathered data on production, foreign trade, and technology. This was mainly from annual reports published by the National Association of Vehicle Manufacturers (Associação Nacional dos Fabricantes de Veículos Automotores [ANFAVEA]). In addition, we studied academic documents (books, dissertations, theses, research reports) on the industry. All these data sources were used to examine the historical evolution of the industry, although some had a specific purpose related to our framework. For example, we used reports from the IBGE, BACEN, and ANFAVEA to make sense of macro changes and newspaper articles to identify changes in governmentindustry relationships and the rules of the game (see Table 2).

Table 2

Data Analysis

\begin{tabular}{ccc}
\hline Category & Source & Insights obtained from sources \\
\hline Document analysis & IBGE , BACEN, and ANFAVEA & Economic performance \\
& $\begin{array}{c}\text { reports } \\
\text { Industry performance }\end{array}$ \\
\hline
\end{tabular}

Political and economic context

Media analysis O Estado de São Paulo (online
archive)
Basis of exchange between government and the industry

Rules of the game (incentives and constraints)

Note. Source: Compiled by the authors. 
We carried out media analysis to make sense of changes over time in the macro environment, the rules of the game, and industry responses. However, sources are not exempt from limitations: newspapers are not free from ideology and distortion cannot be ignored. Thus, we discarded opinion articles, such as editorials. Despite these shortcomings, using newspapers as a source in longitudinal studies has several advantages. First, newspapers traditionally attempt to cover all the different sides involved when approaching an issue. Second, newspapers allow the evolution of political and economic contexts to be followed over a long period of time, which is important when the goal is to understand the dynamics of interdependencies of co-evolving entities. We focused on one newspaper, ESP, which is a major national daily Brazilian newspaper, founded in 1875. This newspaper's entire archive is available online.

By entering the keywords indústria automotiva (automotive industry) into the online ESP archive, we obtained 14,000 articles for the period between 1900 and 2014. Given that analyzing all these articles would be time and cost intensive, and because we were interested in associating clear changes in macroeconomic and political environments and shifts in government policies related to the performance of the automotive industry, we conducted a detailed qualitative analysis only for the years in which we observed great reductions in GDP growth. In Phase I, for example, this occurred in 1974 when GDP growth was $8.2 \%$, falling from $14 \%$ in the previous year. For the analysis of Phase II, we focused on 1981, when GDP growth was $-4.3 \%$, falling from $3.2 \%$ in 1980. For the analysis of Phase III, we focused on 1990, when GDP growth was $-4.3 \%$, falling from $3.2 \%$ in 1989. Finally, in Phase IV, we analyzed 2009 , when GDP growth was $-0.1 \%$, falling from $5.1 \%$ in 2008 . Within each period, we focused on the years of greater economic shrinkage because economic downturns are likely to lead to both industry and government responses in overcoming the effects of crisis. Table 3 presents the years to be analyzed.

Table 3

Years to Be Analyzed (in Bold)

\begin{tabular}{ccc}
\hline Phase & Year & GDP growth \\
\hline \multirow{3}{*}{ Phase I (1964-1974) } & 1973 & $14.0 \%$ \\
\cline { 2 - 3 } & $\mathbf{1 9 7 4}$ & $8.2 \%$ \\
\cline { 2 - 3 } & 1975 & $5.2 \%$ \\
\cline { 2 - 3 } Phase II (1975-1989) & 1980 & $3.2 \%$ \\
\cline { 2 - 3 } & $\mathbf{1 9 8 1}$ & $-4.3 \%$ \\
\hline \multirow{3}{*}{ Phase III (1990-2002) } & 1982 & $0.8 \%$ \\
\cline { 2 - 3 } & 1989 & $3.2 \%$ \\
\hline & $\mathbf{1 9 9 0}$ & $-4.3 \%$ \\
\hline \multirow{2}{*}{ Phase IV (2003-2014) } & 1991 & $1.0 \%$ \\
\cline { 2 - 3 } & 2008 & $5.1 \%$ \\
\hline & $\mathbf{2 0 0 9}$ & $-0.1 \%$ \\
\hline
\end{tabular}

Note. Source: Compiled by the authors.

After defining the years to be analyzed, we proceeded with the archival data collection. Table 4 below summarizes the number of articles analyzed in each selected year. 
Table 4

Number of Articles Analyzed (Per Year)

\begin{tabular}{cc}
\hline Phase & Number of ESP articles \\
\hline Phase I (1974) & 223 \\
\hline Phase II (1981) & 363 \\
\hline Phase III (1990) & 236 \\
\hline Phase IV (2009) & 166 \\
\hline
\end{tabular}

Note. Source: Compiled by the authors.

The reading of all selected articles led to the inclusion of subjects that related to our categories of analysis. First, we considered the economic and political context of each analysis period, selecting those events that were most enduring and representative of each phase so as to make sense of co-evolution. This was followed by the choice of paragraphs whose content addressed the analysis categories (e.g., the rules of the game) and related processes, such as industry-government relationships, interdependencies between these actors, and disputes and compromises between them. Finally, we examined the industry's performance (production, foreign trade, and technology) by drawing upon industry reports, such as those specified previously in this section. Table 5 summarizes the categories of analysis.

Table 5

Analysis Categories

\begin{tabular}{|c|c|c|}
\hline Political Context & $\begin{array}{c}\text { Political regime } \\
\text { (democratic and non-democratic) }\end{array}$ & $\begin{array}{l}\text { Government-business relationship } \\
\text { Developmental state } \\
\text { (Evans, 1979; Gereffi, 1990; } \\
\text { Schneider, 2009, 2015) }\end{array}$ \\
\hline Economic Context & $\begin{array}{l}\text { Economic growth rate } \\
\text { Automotive industry's share of } \\
\text { industrial GDP increased }\end{array}$ & $\begin{array}{l}\text { Government intervention } \\
\text { (incentives, subsidy and protection) } \\
\text { (Lazzarini et al., 2015; Schapiro, } \\
\text { 2017) }\end{array}$ \\
\hline $\begin{array}{l}\text { Basis of exchange between } \\
\text { government and industry }\end{array}$ & $\begin{array}{l}\text { Government priorities } \\
\text { Industry priorities }\end{array}$ & $\begin{array}{c}\text { Co-evolution political perspective } \\
\text { (Child } \text { et al., 2013; Dieleman \& } \\
\text { Sachs, 2008; Rodrigues \& Child, } \\
\text { 2008) }\end{array}$ \\
\hline $\begin{array}{l}\text { Outcomes of industry- } \\
\text { government exchange }\end{array}$ & $\begin{array}{l}\text { Convergence of interests } \\
\text { Rules of the game }\end{array}$ & $\begin{array}{c}\text { Institutional construction } \\
\text { (interests and interdependence) } \\
\text { (Fligstein, 2001; North, 1990; Scott, } \\
\text { 2008) }\end{array}$ \\
\hline
\end{tabular}

Note. Source: The authors.

In order to make sense of the industry through macro variables and the role of the rules of the game in the studied years $(1974,1981,1990,2009)$, we took the GDP performance (economic growth compared to the immediate years before and after) and industry performance (automotive production compared to the immediate years before and after, and the contribution of the industry within industrial GDP) as a reference and explored the underlying motivations of both sides in making their respective demands and responses. In particular, we investigated how the rules of the game were set up or changed following these demands. Even though a causality relationship "demonstrates that variable $\mathrm{x}$ leads to outcome $\mathrm{y}$, and that y was not caused spuriously by a third variable z" (Gibbert, Ruigrok, \& Wicki, 
2008 , p. 1466) - and is a key feature of case study internal or "logical validity" - we acknowledge that this relationship is explained more by "loops than by lines" (Pettigrew, 1990, p. 270). Our rich dataset allowed us to move beyond causal homogeneity (Welch, Piekkari, Plakoyiannaki, \& PaavilainenMäntymäki, 2011). In this study, we used the unique opportunities offered by longitudinal research to "reveal multiple sources and loops of causation and connectivity" (Pettigrew, 1990, p. 271); or as Jones and Khanna (2008) state, environments change and so relationships between variables change, and, thus, understanding these changes matters. To make sense of the relationships between the macro and meso variables, we relied on different iterations and triangulation of information, a measure to enhance construct validity (Gibbert et al., 2008). Consensus between the authors was reached in data interpretation and for the whole analysis.

\section{Findings}

In this section, we present the details of the automotive industry through its macro environment and the resulting rules of the game by describing the political and economic context of each phase. The conditions that led to the development and performance of the industry are also highlighted. Table 6 displays GDP growth and the industry's importance in each period.

Table 6

GDP Growth and Industry's Relevance

\begin{tabular}{cccc}
\hline \multirow{2}{*}{ Phase } & Year & GDP growth & $\begin{array}{c}\text { Automotive industry's } \\
\text { share of industrial } \\
\text { GDP }\end{array}$ \\
\hline \multirow{3}{*}{ Phase I (1964-1974) } & 1973 & $14.0 \%$ & $17.3 \%$ \\
\cline { 2 - 4 } & $\mathbf{1 9 7 4}$ & $8.2 \%$ & $18.6 \%$ \\
\cline { 2 - 4 } & 1975 & $5.2 \%$ & $20.6 \%$ \\
\hline \multirow{3}{*}{ Phase II (1975-1989) } & 1980 & $3.2 \%$ & $13.3 \%$ \\
\cline { 2 - 4 } & $\mathbf{1 9 8 1}$ & $-4.3 \%$ & $11.5 \%$ \\
\hline \multirow{3}{*}{ Phase III (1990-2002) } & 1982 & $0.8 \%$ & $12.8 \%$ \\
& 1989 & $3.2 \%$ & $10.9 \%$ \\
\cline { 2 - 4 } & $\mathbf{1 9 9 0}$ & $-4.3 \%$ & $10.6 \%$ \\
\hline \multirow{3}{*}{ Phase IV (2003-2014) } & 1991 & $1.0 \%$ & $10.8 \%$ \\
\hline & $\mathbf{2 0 0 8}$ & $5.1 \%$ & $17.8 \%$ \\
\hline & $\mathbf{2 0 0 9}$ & $-0.1 \%$ & $19.7 \%$ \\
\hline
\end{tabular}

Note. Source: Compiled by the authors.

\section{Phase I - Import substitution, industry inception, and its consolidation (1964-1974)}

Since the 1920s, cars have been imported and assembled in Brazil. However, due to the increasing burden of these imports on the balance of payments (from less than 5\% of total Brazilian imports in 1945 to more than $14 \%$ in 1952), the Kubitschek government (1956-1960) launched an ambitious automotive program aimed at manufacturing vehicles in Brazil (Shapiro, 1994). The government defined a series of incentives, such as fiscal benefits and advantageous conditions for importing capital goods (machines and equipment), to attract firms interested in investing in the country (Gattás, 1981). 
As a result of these actions, several manufacturers arrived in Brazil, including Ford, General Motors, and Volkswagen. Over the following 18 years (1956-1974), production of vehicles increased from 30,000 units in 1957 to 859,237 units in 1974 (ANFAVEA, 2016). Accordingly, the automotive industry's share of industrial GDP in the country increased - it accounted for $13.82 \%$ in 1968, but reached $20.6 \%$ in 1975 (ANFAVEA, 2016).

Much of the economic and industrial growth in this phase occurred during the period of military dictatorship, especially during the miracle years (1968-1973) when the country's average annual economic growth was above $10 \%$. This period coincided with the consolidation of the military regime, also known as the plumber years. The development of the automotive industry required investment in infrastructure, which was a favored target of the military governments (Fausto, 2000). The agreement and sharing of interests of the automotive industry and government, from the presidency of Juscelino Kubitschek to the military governments, represented a convergence (Roehe, 2011). As a consequence, both the country's economy and the sector's performance became closely interdependent.

At this time (1968-1973), the economy as a whole and the automotive industry in particular started to feel the effects of the oil crisis, which had severely hit the world economy. A fourfold increase in the price of oil during 1973 and 1974 had a substantial impact on the balance of foreign trade, transforming the automotive industry from a growth lever into the Achilles heel of the country's economic development. Such a situation required a revision of the rules of the game for the industry. While previous rules resulted from convergent interests of the government (to reduce the foreign trade deficit and leverage Brazilian industrialization) and industry (to increase their output), from the mid1970s their interests increasingly diverged. However, given government-industry interdependencies, the challenge was to redefine the existing rules of the game and create new ones that were equally convergent for both parties' respective interests.

Following the effects of the oil crisis, the government's intention was to reduce fuel consumption, promote exports, and stimulate the development of new technologies aimed at reducing Brazil's dependence on foreign oil. Given that the latter could be achieved only in the long term, the priority became the alteration of untenable production levels. However, limiting production meant breaking a taboo from the 1964 revolution. Although the government did not intend to shift its economic model based on developmentalism, and as it became clear that growth above $10 \%$ was no longer feasible, the government's logic changed to constraining access to credit and dropping incentives. Mitigating the burden of oil imports was, however, a more challenging issue: vehicle exports were almost non-existent between 1957 and 1973, but they became a critical issue thereafter for both the government and industry as exports increased. In 1974, the industry exported 64,678 vehicles to 50 countries, $264 \%$ more than in 1973, when it exported 24,506 (ANFAVEA, 2016).

Like exports, technology became a major concern for the government when the sale of more powerful, high performance cars (leveraged by easy credit and cheaper oil) became untenable. From 1974, the government demanded that smaller, more economical vehicles be manufactured. In addition, the oil crisis led the government to prioritize ethanol as an alternative fuel. Table 7 summarizes the main findings for Phase I. 
Table 7

Co-evolution Categories (Phase I)

\begin{tabular}{|c|c|}
\hline Political Context & $\begin{array}{l}\text { Military dictatorship } \\
\text { Active role of the state in the economy }\end{array}$ \\
\hline Economic Context & $\begin{array}{c}\text { Higher economic growth } \\
\text { Increasing importance of the automotive industry in } \\
\text { industrial GDP }\end{array}$ \\
\hline $\begin{array}{c}\text { Basis of exchange between government } \\
\text { and industry }\end{array}$ & $\begin{array}{c}\frac{\text { Government priority }}{\text { Production, instead of foreign trade and technology }} \\
\frac{\text { Industry priorities }}{\text { Advantageous conditions for implementing the industry }} \\
\text { Internal market }\end{array}$ \\
\hline $\begin{array}{c}\text { Outcomes of industry-government } \\
\text { exchange }\end{array}$ & $\begin{array}{l}\text { Increasing convergence of interests } \\
\text { Rules of the game (production) }\end{array}$ \\
\hline
\end{tabular}

Note. Source: The authors.

\section{Phase II - Alternative fuel and exports (1975-1989)}

In 1975, the automotive industry was responsible for $20.6 \%$ of total industrial GDP. As the automotive industry reached its peak GDP contribution, several issues emerged that affected the interests of the industry and government, which up until that time had converged. First, when oil prices skyrocketed, countries heavily dependent on oil imports, such as Brazil, witnessed a rapid increase in trade deficits. At that time, Brazil imported around $80 \%$ of the oil it needed. Thus, when prices increased 10-fold within a few years in the 1970s, the military regime decided Brazil had to be less dependent on this fuel source. Second, in order to prevent inflation from escalating, the government limited credit and, hence, the financing of durable goods such as cars (Roehe, 2011). Oil price increases, high inflation, lower economic growth, and less credit affected domestic vehicle consumption, which fell sharply. In spite of the importance of the automotive industry to the country's economy, the deepening of the economic crisis provided evidence that interests were gradually becoming irreconcilable. To no avail the industry made several demands to the government, including a reduction in vehicle taxes, which were among the highest in the world (30-35\% of the final product price). The government argued that tax reduction was not consistent with the rigid fiscal policy followed at that time and it could not relinquish such an important source of revenue. As a result of the worsening macroeconomic scenario, Brazilian automotive industry production began to decline. In 1981, production output fell to its lowest level since the start of the automotive industry in 1956. However, the situation continued to worsen throughout the 1980 s and by 1989 , vehicle production was down $13 \%$ compared to a decade earlier. As a result, the automotive industry lost importance within the economy as a whole, and its share of industrial GDP decreased from 20.6\% in 1975 to $10.9 \%$ in 1989 (ANFAVEA, 2016).

Still within this period, issues that had not been as significant as in the Phase I, such as exports and technology, became priorities. The industry sought to increase exports to compensate for the decline of the internal market in Brazil. The government, in turn, needed foreign currency to service debt payments and pay for imports, especially oil (Anderson, 1999), which had gained importance in the balance of trade. The automotive industry played a central role within the government's strategy to increase exports. A series of incentives was granted to the industry, including financing for production directed at exports, extending credit, and more favorable conditions for paying interest. From 1976 to 1989, vehicle exports increased by 900\%. While in 1970, the industry exported only 409 units, in 1988 
exports amounted to 253,720 vehicles. In 1974 , the share of total vehicle exports amounted to $7.1 \%$, but by 1990 , approximately $20.5 \%$ of total vehicle production was for foreign markets (ANFAVEA, 2016).

In order to ease the heavy costs of oil imports, the search for an alternative fuel became a government priority. Ethanol was viewed as a way to reduce vulnerability and, thus, in 1975 the National Ethanol Program (Programa Nacional do Álcool [Próalcool]) was created. Heavily subsidized by the government and never particularly efficient or cost effective (Schneider, 2015), the program involved ministries, public research institutes, and institutions, such as ANFAVEA; the Cane, Sugar, and Ethanol Cooperative of São Paulo (Cooperativa de Cana, Acúcar e Álcool de São Paulo [Copersucar]); domestic sugar producers; and MNEs (mainly Volkswagen and Fiat). As a result of these concerted efforts, in 1979 less than $1 \%$ of new registered vehicles were fueled by ethanol, but in 1985 this proportion amounted to almost $85 \%$ (ANFAVEA, 2016).

As the economic crisis triggered by the oil crisis hit both the government and automotive industry, their interests became even more intertwined. Even though the government made decisions that were against the automotive industry's interests, the government depended on the industry to increase exports and to develop and produce vehicles fueled by ethanol. The industry, in turn, depended on government (and its agencies, such as ministries and research institutes) to provide incentives to sugar cane producers and get consumers to buy alcohol-powered cars (Schneider, 2015), thus preventing greater damage. In contrast to the Phase I, instead of focusing simply on output and exports, new fuel technology became priorities for both players. Table 8 summarizes the main findings for Phase II.

Table 8

Co-evolution Categories (Phase II)

\begin{tabular}{|c|c|}
\hline Political Context & Military dictatorship \\
\hline \multirow{4}{*}{ Economic Context } & Lower economic growth \\
\hline & Oil shock (high cost of oil imports) \\
\hline & High inflation \\
\hline & Lower share of the automotive industry in industrial GDP \\
\hline \multirow{9}{*}{$\begin{array}{l}\text { Basis of exchange of government } \\
\text { and industry }\end{array}$} & $\underline{\text { Government priorities }}$ \\
\hline & Price control \\
\hline & Export promotion \\
\hline & Development of alternative fuel technology \\
\hline & Promotion of sugar and alcohol production \\
\hline & $\underline{\text { Industry priorities }}$ \\
\hline & Increase exports \\
\hline & Compensate for the decline of the internal market in Brazil \\
\hline & $\begin{array}{l}\text { Respond to the government's demand of developing engines that use } \\
\text { alternative fuel }\end{array}$ \\
\hline $\begin{array}{l}\text { Outcomes of industry-government } \\
\text { exchange }\end{array}$ & $\begin{array}{c}\text { Lower and then higher degree of convergence of interests } \\
\text { Rules of the game } \\
\text { (foreign trade and technology) }\end{array}$ \\
\hline
\end{tabular}

Note. Source: The authors.

Phase III - Increasing competition and modernization (1990-2002)

After 25 years of military rule (1964-1985) and a transitional period (1986-1989), Collor de Mello (1990-1992) was elected president of Brazil in 1989, but resigned in 1992 after corruption 
charges. The vice-president, Itamar Franco (1992-1994), took power. Their radically different styles can be illustrated by the two following anecdotes, both related to the automotive industry. Collor de Mello famously compared Brazilian cars to horse wagons; Franco, an older and more traditional politician who was more associated with simplicity, suggested that Volkswagen should restart production of its famous Beetle, which it had stopped years before. Following the president's suggestion, the German manufacturer restarted production of the Beetle. More than simply illustrating the individual government styles of the two presidents, these anecdotes highlight the value of cars within Brazilian society, the importance of the automotive industry to the country's economy, and the close links between politics and industry.

Even though the country had recovered political normality, from an economic viewpoint, the situation continued to be chaotic and inflation soared to levels not seen before. After a series of failed attempts to control inflation, in 1994 a successful economic stabilization plan (the Real Plan) brought inflation rates down to levels not experienced in more than a decade. In addition, other macroeconomic reforms were implemented, including trade liberalization, privatization, and the creation of Mercosur (the Southern Common Market of the South), an economic bloc composed of Argentina, Brazil, Paraguay, and Uruguay. The adoption of these pro-market policies helped to leverage economic growth (1.95\% on average per year between 1990 and 2002) and boost regional trade and investment flows.

At the industry level, the automotive industry was far from being as important as in Phase I. In 1990, the automotive sector only accounted for $10.6 \%$ of industrial GDP (ANFAVEA, 2016). The lower interdependence that resulted did not mean that the government and industry were no longer locked in. On the contrary, as previously stated, the collaborative nature of the relationship (Schneider, 2015) from its very beginning had set the basis for the subsequent relationship. As in the past, a series of fiscal incentives were granted to the industry.

In response to the crisis at the beginning of the 1990s, the new government sought to promote and modernize this industry through policies known as Industry Agreements (1992-1994) and the New Automotive Regime (1995-1999). These policies involved different actors, such as the government, labor unions, automotive industry, vehicle distributors, and auto motive parts providers. They were based on a shared view that industry production and sales had decreased significantly in the 1980s; that relationships across government, industry, and labor had become chronically poor; and that the Brazilian automotive industry was doomed to disappear due to the rapid modernization of the Japanese and Korean automotive industries.

The first agreement, signed in 1992, comprised several aspects such as vehicle price reduction, stability of employment levels, and vehicle financing. The second, signed in 1993, focused on production, investment, redefinition of financing rules for the acquisition of buses and trucks, vehicle price reduction (tax and profit margin reductions), and salary increases. In addition, it offered tax incentives on vehicles with $1,000 \mathrm{~cm}^{3}$ engines (popular cars) that would be taxed at $0.1 \%$. Finally, the third agreement, signed in 1995, focused on trade issues as imports had increased substantially following the creation of Mercosur.

Later on, the government launched the New Automotive Regime (1995-1999), which aimed to modernize the industry, improve competitiveness, and foster investment by attracting foreign capital and increasing competition within the industry. As in the past, this regime adopted similar mechanisms (subsidies and trade barriers) to attract MNEs, such as import quotas, local content requirements, tax concessions (conditional on export performance), and incentives for MNEs that establish plants in less developed areas (Barros \& Pedro, 2012; Consoni, 2004).

Economic stabilization brought by the Real Plan, alongside industry agreements (1992-1994) and the New Automotive Regime (1995-1999), boosted car production, consumption, and imports. Total production of vehicles increased from 914,466 units in 1990, which was lower than 15 years earlier, to 1,791,530 in 2002, although this was lower than a peak of 2,069,703 in 1997 before the Asian crisis. Thus, in contrast to the 1980s when production had stagnated, in the 1990s Brazilian automotive production boomed (ANFAVEA, 2016). Tax concessions for cars with $1,000 \mathrm{~cm}^{3}$ engines contributed 
substantively to increased internal demand. The registration of cars with these engines increased sharply from less than 5\% of total cars produced in 1990 to nearly $67 \%$ of the total in 2002. As a result, the industry again increased its share of Brazilian industrial GDP from 10.8\% in 1990 to $12.9 \%$ in 2002, although this was far behind the highs reached in the mid-1970s.

In foreign trade terms, two key events in that period - trade liberalization and the creation of Mercosur - substantially affected trade balances and the automotive industry (ANFAVEA, 2006). After a long period of closed markets, trade tariff reductions led to a substantial increase in car imports. Whereas in 1990, only 115 vehicles were imported, in 1995 the import volume reached 370,000 vehicles, falling in 2002 to nearly 110,000 vehicles. Exports also increased - from 187,000 in 1991 to 424,000 in 2002 - but not as much as imports. Another decisive factor in leveraging foreign trade was the creation of Mercosur: $64 \%$ of Brazilian exports were to countries in the common market - mainly Argentina, which alone received 75\% of Brazil's total vehicle exports to Mercosur (ANFAVEA, 2006).

Both macroeconomic and industry shifts affected the dynamics and competitiveness of the automotive industry, the strategy of MNEs, and their R\&D activities. Carmakers in Brazil had already modernized their industrial operations (change of quality, productivity, and competitiveness patterns), built new plants, and renewed their product portfolios. Because of government incentives, several other manufacturers arrived in Brazil (this was the third wave - the first being in the 1950s and the second in 1970s). Even though the government established specific policies for the industry, which were successful in attracting foreign capital, the government disregarded mechanisms to stimulate and promote R\&D (Schapiro, 2017). Incentives were primarily for the expansion of production capacity rather than the broadening of local technological abilities. Selling popular cars largely led to greater specialization of MNE subsidiaries in this segment and, hence, to carmakers' strategies regarding new models (Consoni, 2004). In contrast to the 1980s, the share of ethanol-fueled cars decreased sharply in the 1990s. Whereas in 1985, nearly $85 \%$ of registered new vehicles were fueled by ethanol, in 1995 this proportion was less than 3\% (ANFAVEA, 2016). Table 9 summarizes the main findings for Phase III.

Table 9

Co-evolution Categories (Phase III)

\begin{tabular}{cc}
\hline Political Context & Return of democracy \\
& More market-oriented governments \\
\hline Economic Context & Economic stabilization \\
Trade liberalization & Privatization \\
Creation of Mercosur \\
Lower share of the automotive industry within industrial \\
GDP \\
\hline $\begin{array}{c}\text { Government priorities } \\
\text { industry }\end{array}$ \\
Modernization of the industry \\
Increase competition \\
Improve competitiveness \\
Attract new MNEs \\
Macroeconomic stabilization
\end{tabular}


Table 9 (continued)

\begin{tabular}{cc}
\hline $\begin{array}{c}\text { Basis of exchange of government and } \\
\text { industry }\end{array}$ & $\begin{array}{c}\text { Industry priorities } \\
\text { Modernize products, plants, and production process } \\
\text { Incentives (tax concessions) for "popular" cars }\end{array}$ \\
\hline $\begin{array}{c}\text { Outcomes of industry-government } \\
\text { exchange }\end{array}$ & Increasing convergence of interests \\
& Rules of the game (foreign trade and production) \\
\hline
\end{tabular}

Note. Source: The authors.

\section{Phase IV - Renewed focus on production (2003-2014)}

With a more favorable international economic scenario (higher demand and commodity prices), Brazilian GDP growth averaged 3.85\% between 2001 and 2012, in contrast to $2.54 \%$ and $1.57 \%$ in the 1990s and 1980s, respectively (IBGE, n.d.). Under the Workers' Party, "with its economic model of pumping up consumption through social welfare transfer, pay rises and increased access to credit" (Financial Times, 2013), the automotive industry boomed. Production almost doubled, increasing from $1,827,791$ units in 2003 to 3,172,750 units in 2014, making Brazil one of the largest vehicle manufacturers in the world in 2014 (the Organisation Internationale des Constructeurs d'Automobiles [OICA], 2016). Accordingly, the share of the automotive industry in Brazilian industrial GDP increased again, from $12.5 \%$ in 2003 to $20.4 \%$ in 2014 - levels not seen since 1975 . As well as their strategies, this increasing interdependence intertwined the fates of government and industry. However, this did not mean changes in the rules of the game regarding innovation. Instead, government regulation aimed to foster production and economic growth.

To sustain this boom, a combination of tax reductions and credit easing was widely used to leverage sales and production - mainly after the global economic crisis in 2008, which had severely hit the automotive industry worldwide. In the aftermath of the crisis, to prevent sales from falling sharply, representatives of the automotive industry defended an aggressive policy of reducing interest rates in order to increase credit. The industry performed excellently after the government agreed to reduce taxes, operating at full capacity and planning a new investment cycle. As one of the CEOs of the main vehicle manufacturers claimed, the decision to continue to offer tax concessions demonstrated that the government was concerned about GDP. Moreover, the CEO added that the industry had much to contribute to the country's economic output.

Even though production increased substantially and Brazil ranked among the world's major vehicle producers, the country was not among the top exporters. Furthermore, exports were quite irregular. In 2003, the industry exported 535,980 vehicles. Two years later, it sent 897,144 vehicles abroad. In 2012, however, the export volume fell to 472,046 units. In terms of production, the industry exported between $13.8 \%$ (2012) and 35.5\% (2005) of total manufactured vehicles produced in the country. Some markets lost importance, such as the United States and European Union, whereas others, such as Argentina, alone accounted for more than 70\% of Brazilian vehicle exports in 2011 (ANFAVEA, 2016).

Half a century after its creation, and in spite of its importance to the Brazilian economy, technology development in the industry did not yet become a government priority like in other countries. Even though high-ranking public authorities had stated that the government would stimulate the manufacturing of green vehicles, boosting sales to leverage economic growth and maintaining job levels seemed to be more important than technological innovation. Although the Brazilian automotive industry began to sell flexible-fuel cars in 2003, which was a major innovation and outcome, in terms of newer technologies such as hybrid, electric, and fuel-cell vehicles, the Brazilian industry still lags far behind the rest of the world (Olmos, 2013). 
In 2012, the government launched a five-year program called the Incentive Program for Technological Innovation Incentive and Strengthening of the Motor Vehicle Production Chain (InovarAuto). It aims was to attract new investments in order to increase the level of local content production, which would favor the auto parts industry. Increasing spending in engineering, industrial technology, and suppliers' qualifications, as well as investment in R\&D and the manufacturing of more economical, efficient, and safer vehicles, was seen as a way of reducing the technological gap between Brazil and developed countries (Castro, Barros, \& Vaz, 2014; Schapiro, 2017). Here, the government looked to attract more investment, increase the competitiveness of vehicles manufactured in Brazil, foster local and regional (through Mercosur) manufacturing of automotive parts, and create more jobs. ANFAVEA estimated that the Inovar-Auto program would be responsible for nearly US \$ 30 billion in investments made by the industry, including new plants and the expansion of existing ones. The outcomes of this program in terms of effective technology development have not, however, looked very promising. Even though opportunities within the automotive industry include the development of hybrid and electric vehicles, government incentives have broadly favored traditional vehicles (Schapiro, 2017). Table 10 summarizes the main findings for Phase IV.

Table 10

Co-evolution Categories (Phase IV)

\begin{tabular}{|c|c|}
\hline Political Context & $\begin{array}{c}\text { Democracy } \\
\text { Workers' Party in power }\end{array}$ \\
\hline \multirow{3}{*}{ Economic Context } & Economic growth based on pumping up consumption \\
\hline & Easing credit \\
\hline & Greater share of the automotive industry in industrial GDP \\
\hline \multirow{7}{*}{$\begin{array}{l}\text { Basis of exchange of government and } \\
\text { industry }\end{array}$} & Government priorities \\
\hline & Job creation \\
\hline & Increase consumption \\
\hline & Innovation \\
\hline & Industry priorities \\
\hline & Incentives \\
\hline & Internal market \\
\hline \multirow{2}{*}{$\begin{array}{l}\text { Outcomes of industry-government } \\
\text { exchange }\end{array}$} & Higher degree of convergence of interests \\
\hline & Rules of the game (production and innovation) \\
\hline
\end{tabular}

Note. Source: The authors.

\section{Discussion}

Our research results suggest that the outcomes of exchanges (rules of the game) between government and industry strategies are highly contextual and dependent on political and economic conditions prevailing at a particular moment in time. As these rules changed following economic downturns and political shifts, they reflect the interdependence between the automotive sector and the country's economy. Adopting North's terms, the automotive industry and the Brazilian government have a symbiotic relationship, as do their fates. Six decades after the industry's creation, the government has not succeeded in defining rules that effectively promote a more innovative industry. Instead, the Brazilian automotive industry, which is still highly dependent on government subsidies and protection, 
seems to merely be a sticking-plaster solution to macroeconomic difficulties. Not surprisingly, interdependence is a key driver of the co-evolutionary process between government and industry strategies.

When the Brazilian automotive industry was created in the mid-1950s, the government's main objective was to reduce the country's balance of payments deficit and drive Brazilian industrialization. Rules were defined to attract interested MNEs and, thus, accomplish these aims. The priority of the government was mainly production, and with this, imports would be reduced. From the 1950s to the 1970s, industry and government strategies (economic growth and production growth) distinctively converged. This convergence led to more consensual rules of the game because they responded to the interests of both sides. This convergence also meant that the two players' interests became closely intertwined and, thus, the fate of one depended on that of the other, creating a dependence that marked the posterior evolution of both sides' strategies.

In the mid-1970s, the oil crisis hit the industry, which in less than two decades had become a critical to the country's industrial GDP. The government's strategy was, on the one hand, to restrict internal consumption and, on the other, boost exports and the development of an alternative fuel. As the government could not continue stimulating internal consumption, it had to change the rules of the game, prioritizing exports and the development of ethanol. The automotive industry lost importance in overall industrial GDP and, compared to the previous phase, interest commonality was less evident. However, export increases and the solid development of ethanol were only made possible because of incentives provided by the government. Rules changed to prevent the automotive industry from contributing to the worsening of the economic crisis, and, then again, to foster its contribution to economic recovery.

A political and ideological change in 1990 , led by the first democratically elected government since 1962, meant reductions in heavy protectionism that had prevailed within the Brazilian economy. Changes in rules regarding imports (tariffs were reduced) showed the extent to which the Brazilian automotive industry required modernization. The convergence of interests between the industry and government was low, with rules on trade being imposed by the government. However, the modus operandi quickly shifted again: government-, labor union-, and industry-negotiated rules aimed to reduce vehicle prices, maintain employment levels, and increase production. Later, with the New Automotive Regime, other rules were defined that aimed to modernize the industry, increase competition and competitiveness, and foster investments. Despite changes in the way these rules were defined, consecutive governments never stopped granting incentives and protection to the industry. As a result, as the economy grew, the industry started to regain its past importance. Although during brief periods low endogeneity seemed to prevail, the process soon became highly endogenous again.

From the 2000s, like that which had occurred in Phase I, with easing credit the government facilitated consumption. The rules regarding taxes were changed to boost sales and production. In so doing, government strategy leveraged the industry and increased economic growth. The industry became as important as in the mid-1970s and helped to accomplish government aims. However, the Inovar-Auto program was less successful in the promotion of radical innovations, a phenomenon already happening in this industry in other parts of the world. Overall, a higher degree of convergence of government and industry interests, resulting from the symbiotic relationship between the automotive industry and Brazilian economy, led to the definition of rules of the game that fostered production and - only incremental innovations. There was a lower level of institutional endogeneity because the commonality of interests alongside interdependence led both actors into concerted and coordinated action.

Overall, the economic and political contexts that prevailed, along with changes in the basis of exchanges, gave rise to the rules of the game that the industry responded to in accordance with its own interests. These rules, in turn, affected industry performance in all three categories (production, foreign sales, and technology). The emphasis on one of these dimensions depended on choices made by successive governments. Our findings suggest that Brazilian government strategies for the automotive industry in the periods analyzed predominantly addressed short-term economic and political challenges, giving rise to an industry primarily focused on boosting vehicle production - and occasionally on restricting imports or fostering exports, not because of its vocation, but to resolve trade unbalances. 
There was little concern for innovation and sustainability, except during Phase II, when the industry was involved in the development of ethanol-fueled engines. The kind of industry that took shape in Brazil certainly resulted from a degree of interest convergence between the industry and government, but also from the economic and political challenges relevant to each period of our analysis.

Table 11 presents a summary of our findings for the entire period under analysis. For the automotive industry, the rules of the game varied in incentives and constraints. In all periods except the 1980s, the industry displayed much dependence on the government and its provision of credit for consumption, market protection, and subsidies. It seems that the government considered the industry primarily as a tool to increase consumption and, therefore, to boost economic activities. This interdependence drove the co-evolution process between government and industry strategies. Although interdependence varied, as well as the direction and content of rules, the close relationship between both sides allowed rapid implementation of policy priorities (Schneider, 2015), particularly in the aftermath of the worst economic years.

Table 11

Co-evolution Factors during the Four Analysis Periods

\begin{tabular}{|c|c|c|c|c|}
\hline & 1964-1974 & 1975-1989 & 1990-2002 & 2003-2014 \\
\hline $\begin{array}{c}\text { Political and } \\
\text { economic } \\
\text { context }\end{array}$ & $\begin{array}{c}\text { Military coup } \\
\text { Miracle years } \\
\text { Oil shock }\end{array}$ & $\begin{array}{l}\text { Military governments } \\
\text { Lost decade } \\
\text { Economic instability } \\
\text { High inflation }\end{array}$ & $\begin{array}{c}\text { Return of democracy } \\
\text { Trade liberalization } \\
\text { Creation of Mercosur } \\
\text { Economic stabilization and } \\
\text { privatization }\end{array}$ & $\begin{array}{l}\text { Workers' Party in } \\
\text { power } \\
\text { Easing credit } \\
\text { Facilitating } \\
\text { consumption }\end{array}$ \\
\hline $\begin{array}{c}\text { Basis } \\
\text { of exchange } \\
\text { of } \\
\text { government } \\
\text { and industry }\end{array}$ & $\begin{array}{l}\text { High degree of } \\
\text { interest } \\
\text { convergence } \\
\text { Highly } \\
\text { interdependent }\end{array}$ & $\begin{array}{l}\text { Government } \\
\text { emphasis on exports } \\
\text { Development of } \\
\text { ethanol as a } \\
\text { technological } \\
\text { solution }\end{array}$ & $\begin{array}{l}\text { Less protection by the } \\
\text { government } \\
\text { Government interested in } \\
\text { increasing competition } \\
\text { (arrival of new } \\
\text { competitors) } \\
\text { Industry sought to } \\
\text { increasingly modernize its } \\
\text { products and production } \\
\text { processes }\end{array}$ & $\begin{array}{c}\text { Government interest } \\
\text { in industry's role in } \\
\text { boosting } \\
\text { consumption and } \\
\text { exports } \\
\text { Firms interested in } \\
\text { government tax } \\
\text { concession }\end{array}$ \\
\hline $\begin{array}{l}\text { Rules of the } \\
\text { game }\end{array}$ & $\begin{array}{l}\text { Attraction of } \\
\text { MNEs } \\
\text { Production- } \\
\text { oriented rules } \\
\text { Restrictions on } \\
\text { vehicles imports } \\
\text { Abundant credit } \\
\text { Incentives for the } \\
\text { industry }\end{array}$ & $\begin{array}{l}\text { Incentives for } \\
\text { exporting } \\
\text { New alternatives for } \\
\text { gas } \\
\text { Price control } \\
\text { Restrictions on profit } \\
\text { remittance }\end{array}$ & $\begin{array}{c}\text { Reduction of trade tariffs } \\
\text { Attraction of new MNEs } \\
\text { Tripartite agreements } \\
\text { Tax incentives for popular } \\
\text { cars } \\
\text { Automotive regime } \\
\text { (subsidies, trade barriers, } \\
\text { import quotas, local } \\
\text { content requirements, tax } \\
\text { benefits, and other } \\
\text { incentives) }\end{array}$ & $\begin{array}{c}\text { Tax reductions (still } \\
\text { one of highest in the } \\
\text { world) and } \\
\text { facilitation of } \\
\text { consumers' access to } \\
\text { credit } \\
\text { New program for the } \\
\text { automotive industry } \\
\text { (Inovar-Auto) aimed } \\
\text { at increasing } \\
\text { investment in R\&D } \\
\text { and innovation }\end{array}$ \\
\hline
\end{tabular}


Table 11 (continued)

\begin{tabular}{|c|c|c|c|c|}
\hline & 1964-1974 & 1975-1989 & 1990-2002 & 2003-2014 \\
\hline $\begin{array}{c}\text { Industry } \\
\text { performance }\end{array}$ & $\begin{array}{l}\text { Increasing share } \\
\text { of the industry in } \\
\text { industrial GDP } \\
\text { Less exporting } \\
\text { Little investment } \\
\text { in technology } \\
\text { development }\end{array}$ & $\begin{array}{l}\text { Lower share of the } \\
\text { industry in industrial } \\
\text { GDP } \\
\text { Substantial increase } \\
\text { in vehicle exports } \\
\text { Sales of ethanol- } \\
\text { fueled vehicles } \\
\text { amounted to } 85 \% \text { of } \\
\text { total }\end{array}$ & $\begin{array}{c}\text { Industry GDP share } \\
\text { started increasing again } \\
\text { Increased number of car } \\
\text { assemblers } \\
\text { Production of popular cars } \\
\text { boomed } \\
\text { Increased sales to } \\
\text { Mercosur } \\
\text { Sales of ethanol-fueled } \\
\text { vehicles amounted to less } \\
\text { than } 5 \%\end{array}$ & $\begin{array}{l}\text { Industry share of } \\
\text { industrial GDP at } \\
\text { mid-1970s levels } \\
\text { Brazilian industry } \\
\text { ranked one of the } \\
\text { largest in the world } \\
\text { Investment in hybrid } \\
\text { vehicles }\end{array}$ \\
\hline
\end{tabular}

Note. Source: Compiled by the authors.

\section{Conclusions}

By tracing the evolution of the automotive industry in Brazil, this research has primarily aimed to comprehend the co-evolution between industry strategies and government policies. To this end, we investigated the drivers and outcomes of this co-evolution. Specifically, we examined the basis of exchanges between the government and industry as well as how this shaped the rules of the game policies applied to the industry. Drawing on North's (1990) argument that institutions are created to serve the interests of those with the bargaining power to devise new rules, our research has shown, first, that institutions are appropriately viewed in these contexts as endogenous - they are interest driven and therefore shaped by the priorities of industries and governments; second, interdependence and economic and political circumstances influence the direction and content of the rules of the game, which are defined by the government for the industry. These rules may be defined primarily to resolve macroeconomic difficulties. Third, the role of interdependence in institution-building should be seen conjointly with path dependence. As mentioned by North (1990), institutional incentive structures provided by government determine how the rules of the game evolve and change.

Figure 1 summarizes our findings, which could be refined with further research. The rules of the game are developed from economic and political contexts and types of exchange between government and industry. These rules shape industry strategies on production, technology, and foreign trade.

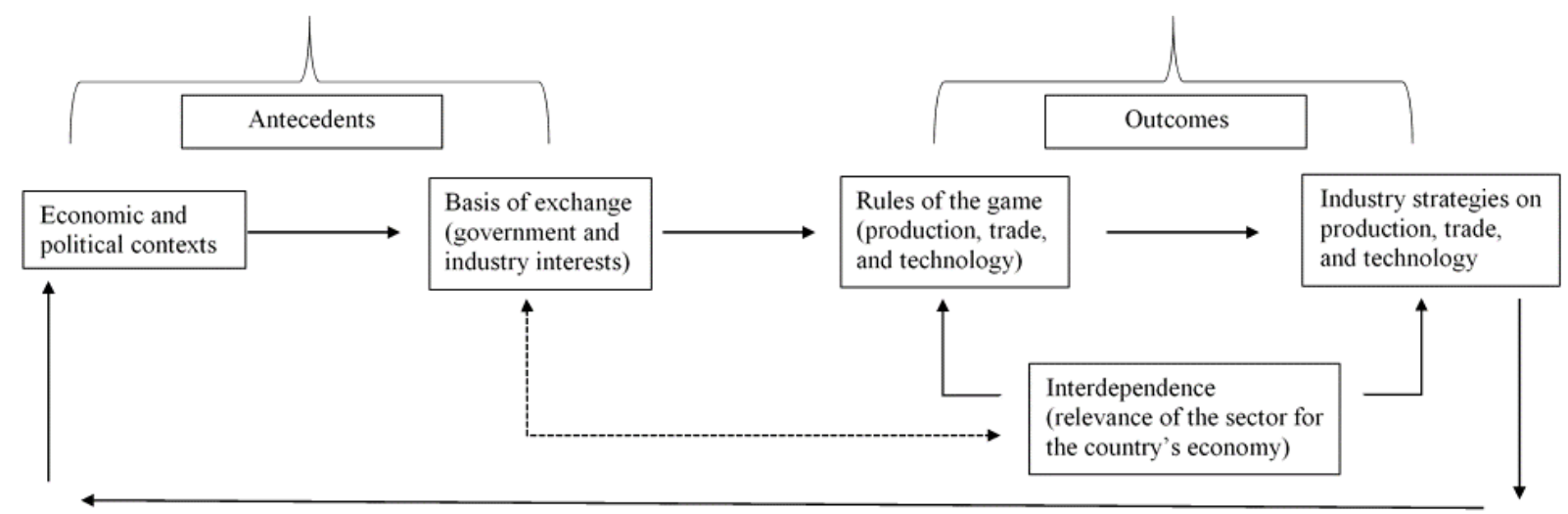

Figure 1. Co-evolution between Context, Interest-based Exchange, Rules of the Game, Industry Strategies, and Interdependencies 
A major theoretical contribution of this study is that it refines our understanding of the rules of the game, particularly their construction and change over time. Instead of being the result of rational government choices, the rules of the game arise from interdependencies between them and different economic sectors. A co-evolution perspective assumes that economic entities influence each other, but only recently has the political nature of this influence been analyzed (Child et al., 2013). This view of co-evolution has brought attention to the relevance of concepts from political science (such as power, influence, interests, and ideology) in disentangling its dynamics. As our study shows, changes in the nature of interdependencies and exchanges between those who make and legitimize the rules and those who shape them are the root of the dynamics of co-evolution. Our study also suggests that interdependencies between industry and the whole economy vary over time and can affect the direction as well as the content of the rules of the game.

Another theoretical implication, derived from our refined understanding of the types of exchanges (give and take) within co-evolution processes, concerns the role of institutional endogeneity (Dieleman $\&$ Sachs, 2008) in understanding the dynamics of co-evolution in emerging economies. Dieleman and Sachs' (2008) main argument is that organizations can modify their environments to fit their needs through political connections. The case of the Brazilian automotive industry shows that endogeneity increases when the interests of industries and governments become coincidental and intertwined. Put differently, as the accomplishment of government interests depends on satisfying industries' interests, the rules of the game assume a more endogenous character. As Dieleman and Sachs (2008) insightfully contend, if it is true that institutions should be seen as endogenous as they can be influenced by the political action of organizations, circumstantial interdependence is another variable that can explain institutional endogeneity.

This study has some limitations. The first relates to the challenge of covering such a complex industry over a long period of time. There were several economic and political shifts throughout the decades and these have multiple implications for the automotive industry. We focused on data regarding production, external trade, and technology; however, we acknowledge that for the dynamics of coevolution between industries and governments to be fully unveiled, the analysis of other data categories is required. Second, due to the impossibility of analyzing all articles on the theme published over 50 years, we chose those articles that appeared in the worst economic year (in terms of economic growth) of each period. We do not ignore the shortcomings of our choice as the dynamics of co-evolution was subjected to events that occurred in years that were not analyzed in this paper. Nevertheless, we believe that this study presents topics for further research that need to be addressed. One suggestion is to compare the dynamics of co-evolution between the automotive industry and government with other institutional settings. Another suggestion is to analyze co-evolution in other industries. Both would help to further illuminate the role of politics and power in co-evolutionary processes as well as political action in the definition of, and changes to, the rules of the game.

\section{Acknowledgements}

The authors would like to thank the BAR Associate Editor for suggestions on how to improve this paper; two anonymous reviewers for helping us to make this paper better; Luciano Costa Póvoa and Ronan Torres Quintão for their careful reading and commenting on earlier drafts; Professor Yaron Ben-Naeh for the discussion on media analysis and for providing us with valuable academic articles on this topic; Gabriella Simas Lopes and Henrique Lucrécio Campolina for their research assistance; and CAPES and UFMG for their financial support. 


\section{References}

Ahlstrom, D., \& Bruton, G. D. (2010). Rapid institutional shifts and the co-evolution of entrepreneurial firms in transition economies. Entrepreneurship Theory and Practice, 34(3), 531-554. https://doi.org/10.1111/j.1540-6520.2010.00373.x

Anderson, P. (1999). Câmaras setoriais: histórico e acordos firmados - 1991 [Texto para Discussão, № 0667]. Rio de Janeiro, RJ: IPEA.

Associação Nacional dos Fabricantes de Veículos Automotores. (2006). Indústria automobilística brasileira 50 anos. Retrieved from http://www.anfavea.com.br/50anos/8.pdf

Associação Nacional dos Fabricantes de Veículos Automotores. (2016). Anuário da indústria automobilística brasileira 2016. Retrieved from http://www.virapagina.com.br/anfavea2016/

Barros, D. C., \& Pedro, L. S. (2012). O papel do BNDES no desenvolvimento do setor automotivo brasileiro. In F. L. de Sousa (Org.), BNDES 60 anos: perspectivas setoriais (Vol. 1, pp. 98-136). Rio de Janeiro: BNDES. Retrieved https://web.bndes.gov.br/bib/jspui/bitstream/1408/938/4/O\%20papel\%20do\%20BNDES\%20no \%20desenvolvimento\%20do\%20setor\%20automotivo-final_P.pdf

Bazuchi, K. R. V., Zacharias, S. A. S., Broering, L. W., Arreola, M. F., \& Bandeira-de-Mello, R. (2013). The role of home country political resources for Brazilian multinational companies. Brazilian Administration Review, 10(4), 415-438. Retrieved from http://www.scielo.br/pdf/bar/v10n4/04.pdf. $\quad$ http://dx.doi.org/10.1590/S180776922013000400004

Biggart, N. W., \& Guillén, M. F. (1999). Developing difference: Social organization and the rise of the auto industries of South Korea, Taiwan, Spain, and Argentina. American Sociological Review, 64(5), 722-747. https://doi.org/10.2307/2657373

Boddewyn, J. J., \& Brewer, T. L. (1994). International-business political behavior: New theoretical directions. Academy of Management Review, 19(1), 119-143. https://doi.org/10.5465/amr.1994.9410122010

Breznitz, D. (2007). Industrial R\&D as a national policy: Horizontal technology policies and industrialstate co-evolution in the growth of the Israeli software industry. Research Policy, 36(9), 14651482. https://doi.org/10.1016/j.respol.2007.06.006

Castro, B. H. R. D., Barros, D. C., \& Vaz, L. F. H. (2014). Panorama da engenharia automotiva no Brasil: Inovação e o apoio do BNDES. BNDES Setorial, 39, 155-196. Retrieved from http://www.bndes.gov.br/SiteBNDES/export/sites/default/bndes_pt/Galerias/Arquivos/conheci mento/bnset/set3905.pdf

Child, J., Lu, Y., \& Tsai, T. (2007). Institutional entrepreneurship in building an environmental protection system for the People's Republic of China. Organization Studies, 28(7), 1013-1034. https://doi.org/10.1177/0170840607078112

Child, J., Rodrigues, S. B., \& Tse, K. K.-T. (2012). The dynamics of influence in corporate co-evolution. Journal of Management Studies, 49(7), 1246-1273. https://doi.org/10.1111/j.14676486.2012.01057.x

Child, J., Tse, K. K.-T., \& Rodrigues, S. B. (2013). The dynamics of corporate co-evolution: A case study of port development in China. Cheltenham (UK) and Norhampton/MA (USA): Edward Elgar. 
Consoni, F. L. (2004). Da tropicalização ao projeto de veículos: Um estudo das competências em desenvolvimento de produtos nas montadoras de automóveis no Brasil (Tese de doutorado). Universidade Estadual de Campinas, Campinas, SP, Brasil.

Cuervo-Cazurra, A., \& Dau, L. A. (2009). Promarket reforms and firm profitability in developing countries. Academy of Management Journal, 52(6), 1348-1368. https://doi.org/10.5465/amj.2009.47085192

Cuervo-Cazurra, A., Inkpen, A., Musacchio, A., \& Ramaswamy. K. (2014). Governments as owners: State-owned multinational companies. Journal of International Business Studies, 45(8), 919-942. https://doi.org/10.1057/jibs.2014.43

Dantas, E., \& Bell, M. (2011). The co-evolution of firm-centered knowledge networks and capabilities in late industrializing countries: The case of Petrobras in the offshore oil innovation system in Brazil. World Development, 39(9), 1570-1591. https://doi.org/10.1016/j.worlddev.2011.02.002

Dieleman, M., \& Sachs, W. M. (2008). Coevolution of institutions and corporations in emerging economies: How the Salim group morphed into an institution of Suharto's crony regime. Journal of Management Studies, 45(7), 1274-1300. https://doi.org/10.1111/j.1467-6486.2008.00793.x

DiMaggio, P., \& Powell, W. W. (1983). The iron cage revisited: Collective rationality and institutional isomorphism in organizational fields. American Sociological Review, 48(2), 147-160. https://doi.org/10.2307/2095101

Djelic, M. L., \& Ainamo, A. (1999). The coevolution of new organizational forms in the fashion industry: A historical and comparative study of France, Italy, and the United States. Organization Science, 10(5), 622-637. https://doi.org/10.1287/orsc.10.5.622

Dunning, J. H., \& Lundan, S. M. (2008). Multinational enterprises and the global economy. Cheltenham: Edward Elgar Publishing.

Eden, L., \& Molot, M. A. (2002). Insiders, outsiders and host country bargains. Journal of International Management, 8(4), 359-388. https://doi.org/10.1016/s1075-4253(02)00095-9

Evans, P. (1979). Dependent development: The alliance of multinational, state, and local capital in Brazil. Princenton: Pricenton University Press.

Fausto, B. (2000). História do Brasil. São Paulo: Universidade de São Paulo.

Fernandes, C. M. A., Bandeira-de-Mello, R., \& Zanni, P. P. (2012). O papel dos fatores políticos na internacionalização de empresas: O caso da Energias de Portugal (EDP) no Brasil. Cadernos EBAPE.BR, 10(2), 435-455. https://doi.org/10.1590/s1679-39512012000200011

Financial Times. (2013, June 25). Brazil's love of the car begins to backfire for political leaders. Financial Times. Retrieved from http://www.ft.com/intl/cms/s/0/d3a1a5de-dd76-11e2-892b00144feab7de.html\#axzz2Xnj2RuG3

Flier, B., Van den Bosch, F. A., \& Volberda, H. W. (2003). Co-evolution in strategic renewal behaviour of British, Dutch and French financial incumbents: Interaction of environmental selection, institutional effects and managerial intentionality. Journal of Management Studies, 40(8), 21632187. https://doi.org/10.1046/j.1467-6486.2003.00416.x

Fligstein, N. (2001). The architecture of markets: An economic sociology of twenty-first-century capitalist societies. Princeton: Princeton University Press.

Funk, J. L. (2009). The co-evolution of technology and methods of standard setting: The case of the mobile phone industry. Journal of Evolutionary Economics, 19(1), 73-93. https://doi.org/10.1007/s00191-008-0108-6 
Gattás, R. (1981). A indústria automobilística e a 2a. revolução industrial no Brasil: Origens e perspectivas. São Paulo: Prelo.

Gereffi, G. (1990). Paths of industrialization: An overview. In G. Gereffi \& D. L. Wyman (Eds.), Manufacturing miracles: Paths of industrialization in Latin America and East Asia (pp. 3-31). Princeton: Princeton University Press.

Gibbert, M., Ruigrok, W., \& Wicki, B. (2008). What passes as a rigorous case study? Strategic Management Journal, 29(13), 1465-1474. http://dx.doi.org/10.1002/smj.722

Grosse, R. (2013). MNEs in Latin America. London: Routledge.

Henisz, W. J., \& Zelner, B. A. (2005). Legitimacy, interest group pressures and institutional change: The case of foreign investors and host country governments. Academy of Management Review, 30(2), 361-382. https://doi.org/10.5465/amr.2005.16387892

Hoffman, A. J. (1999). Institutional evolution and change: Environmentalism and the US chemical industry. Academy of Management Journal, 42(4), 351-371. https://doi.org/10.2307/257008

Huygens, M., Van den Bosch, F. A., Volberda, H. W., \& Baden-Fuller, C. (2001). Co-evolution of firm capabilities and industry competition: Investigating the music industry, 1877-1997. Organization Studies, 22(6), 971-1011. https://doi.org/10.1177/0170840601226004

Instituto Brasileiro de Geografia e Estatística. (n.d.). Sistema nacional de índices de preços ao consumidor - SNIPC. Retrieved from https://sidra.ibge.gov.br/pesquisa/snipc

Jain, S., \& Sharma, D. (2013). Institutional logic migration and industry evolution in emerging economies: The case of telephony in India. Strategic Entrepreneurship Journal, 7(3), 252-271. https://doi.org/10.1002/sej.1160

Kaufman, R. R. (1990). How societies change developmental models or keep them: Reflections on the Latin American Experience in the 1930s and the postwar world. In G. Gereffi \& D. L. Wyman (Eds.), Manufacturing miracles: Paths of industrialization in Latin America and East Asia (pp. 110-138). Princeton: Princeton University Press.

Kostova, T., \& Roth, K. (2002). Adoption of an organizational practice by subsidiaries of multinational corporations: Institutional and relational effects. Academy of Management Journal, 45(1), 215233. https://doi.org/10.2307/3069293

Lampel, J., \& Shamsie, J. (2003). Capabilities in motion: New organizational forms and the reshaping of the Hollywood movie industry. Journal of Management Studies, 40(8), 2189-2210. https://doi.org/10.1046/j.1467-6486.2003.00417.x

Lawton, T., McGuire, S., \& Rajwani, T. (2013). Corporate political activity: A literature review and research agenda. International Journal of Management Reviews, 15(1), 86-105. https://doi.org/10.1111/j.1468-2370.2012.00337.x

Lazzarini, S. G., Musacchio, A., Bandeira-de-Mello, R., \& Marcon, R. (2015). What do state-owned development banks do? Evidence from BNDES, 2002-09. World Development, 66, 237-253. https://doi.org/10.1016/j.worlddev.2014.08.016

Lewin, A. Y., \& Koza, M. P. (2001). Empirical research in co-evolution processes of strategic adaptation and change: The promise and the challenge. Organization Studies, 22(6), v-xii. https://doi.org/10.1177/0170840601226001

Lewin, A. Y., \& Volberda, H. W. (1999). Prolegomena on coevolution: A framework for research on strategy and new organizational forms. Organization Science, 10(5), 519-534. https://doi.org/10.1287/orsc.10.5.519 
Lu, J., Liu, X., Wright, M., \& Filatotchev, I. (2014). International experience and FDI location choices of Chinese firms: The moderating effects of home country government support and host country institutions. Journal of International Business Studies, 45(4), 428-449. https://doi.org/10.1057/jibs.2013.68

Meyer, K. E., \& Peng, M. W. (2016). Theoretical foundations of emerging economy business research. Journal of International Business Studies, 47(1), 3-22. https://doi.org/10.1057/jibs.2015.34

Murmann, J. P. (2013). The co-evolution of industries and important features of their environments. Organization Science, 24(1), 58-78. https://doi.org/10.1287/orsc.1110.0718

Musacchio, A., \& Lazzarini, S. G. (2014). Reinventing state capitalism. Cambridge (MA): Harvard University Press.

Nelson, R. R. (1995). Co-evolution of industry structure, technology and supporting institutions, and the making of comparative advantage. International Journal of the Economics of Business, 2(2), 171184. https://doi.org/10.1080/758519306

North, D. C. (1990). Institutions, institutional change and economic performance. Cambridge: Cambridge University Press.

North, D. C. (2001). Economic performance through time. In M. C. Brinton \& V. Nee (Eds.), The new institutionalism in sociology (pp. 247-257). Stanford: Stanford University Press.

Olmos, M. (2013, July 17). Brasil assiste, à distância, à reinvenção dos carros. Valor Econômico. Retrieved from http://www.valor.com.br/brasil/3200764/brasil-assiste-distancia-reinvencao-doscarros

Organisation Internationale des Constructeurs d'Automobiles. (2016). Production statistics. Retrieved from http://www.oica.net/category/production-statistics/

Peng, M. W., Wang, D. Y., \& Jiang, Y. (2008). An institution-based view of international business strategy: A focus on emerging economies. Journal of International Business Studies, 39(5), 920936. https://doi.org/10.1057/palgrave.jibs. 8400377

Pettigrew, A. M. (1990). Longitudinal field research on change: Theory and practice. Organization Science, 1(3), 267-292. https://doi.org/10.1287/orsc.1.3.267

Rajwani, T., \& Liedong, T. A. (2015). Political activity and firm performance within nonmarket research: A review and international comparative assessment. Journal of World Business, 50(2), 273-283. https://doi.org/10.1016/j.jwb.2014.10.004

Rodrigues, S. B., \& Child, J. (2003). Co-evolution in an institutionalized environment. Journal of Management Studies, 40(8), 2137-2162. https://doi.org/10.1046/j.1467-6486.2003.00415.x

Rodrigues, S. B., \& Child, J. (2008). Corporate co-evolution: A political perspective (Vol. 4). Chichester: John Wiley \& Sons.

Roehe, N. S. (2011). A indústria automobilística e a política econômica do governo Geisel: Tensão em uma parceria histórica (1974-1978) (Tese de doutorado). Pontifícia Universidade Católica do Rio Grande do Sul, Porto Alegre, RS, Brasil. Retrieved from http://repositorio.pucrs.br/dspace/handle/10923/3953

Schapiro, M. G. (2017). O estador pastor e os incentivos tributários no setor automotivo. Revista de Economia Política, 37(2), 437-455. Retrieved from http://www.rep.org.br/PDF/147-10.PDF. https://doi.org/10.1590/0101-31572017v37n02a10 
Schneider, B. R. (2009). Hierarchical market economies and varieties of capitalism in Latin America. Journal of Latin American Studies, 41(3), 553-575. https://doi.org/10.1017/s0022216x09990186

Schneider, B. R. (2015). The developmental state in Brazil: Comparative and historical perspectives. Brazilian Journal of Political Economy, 35(1), 114-132. Retrieved from http://www.rep.org.br/PDF/138-7.PDF

Scott, W. R. (2008). Institutions and organizations: Ideas and interests. Thousand Oaks: Sage Publications, Inc.

Shapiro, H. (1994). Engines of growth: The state and transnational auto companies in Brazil. Cambridge: Cambridge University Press.

Stallings, B. (1990). The role of foreign capital in economic development. In G. Gereffi \& D. L. Wyman (Eds.), Manufacturing miracles: Paths of industrialization in Latin America and East Asia (pp. 55-89). Princeton: Princeton University Press.

Stopford, J. M. (1994). The growing interdependence between transnational corporations and governments. Transnational Corporations, 3(1), 53-76.

Sun, P., Mellahi, K., \& Wright, M. (2012). The contingent value of corporate political ties. The Academy of Management Perspectives, 26(3), 68-82. https://doi.org/10.5465/amp.2011.0164

Welch, C., Piekkari, R., Plakoyiannaki, E., \& Paavilainen-Mäntymäki, E. (2011). Theorising from case studies: Towards a pluralist future for international business research. Journal of International Business Studies, 42(5), 740-762. https://doi.org/10.1057/jibs.2010.55

Zhao, Z., Anand, J., \& Mitchell, W. (2005). A dual networks perspective on inter-organizational transfer of R\&D capabilities: International joint ventures in the Chinese automotive industry. Journal of Management Studies, 42(1), 127-160. https://doi.org/10.1111/j.1467-6486.2005.00491.x

\section{Authors' Profiles}

Roberto Gonzalez Duarte

Av. Antonio Carlos, 6627, Pampulha, 31270-901, Belo Horizonte, MG, Brazil. E-mail address: rgonzalezduarte@gmail.com

Suzana Braga Rodrigues

Erasmus University Rotterdam, Rotterdam School of Management, 3062 PA, Rotterdam, Netherlands. E-mail address: suzana.braga.rodrigues@gmail.com 